\title{
THE ABSOLUTENESS OF CHRISTIANITY
}

\section{HeNRY STOB}

I shall undertake to speak to you this morning on The Absoluteness of Christianity. As you may suspect, I shall maintain that Christianity is the one absolute and final religion, the only way that leads from man to God, since it is concerned with the single way in which God confronts man redemptively, the Way called Christ, who himself once said: "I am the way ..., no man cometh to the Father but by me."

Before I proceed, however, I must indicate what I mean by the terms Christianity and Absolute. By Christianity I mean that sacred deposit of Grace and Truth which came in Jesus Christ, was anticipated in God's saving dealings with His chosen people Israel, was proclaimed by the Apostles, and is preserved in the Church, which communicates it through the preaching of the Word and the administration of the Sacraments, in the power of the Holy Spirit.

By the absoluteness of Christianity is meant that quality of this religion which lifts it above the relativities of time and circumstance and gives it final and unconditional validity. The English word "absolute" is derived from the participial form of the Latin verb ab-solvere, to be "cut loose," or to be "set free." In the theological and philosophical usage the word is frequently used to describe God, or the highest power or principle which is taken as God, and when so used it is employed to indicate that this Person or Principle is not dependent upon or conditioned by the complexities of finite existence: He or It is "free" of flux and process, raised above the changes of time and history, "cut loose" from the determinants which condition all other entities.

\section{THE PROBLEM}

Now, there are some thinkers who refuse to predicate absoluteness of God, for to predicate absoluteness of God is, they believe, to conceive of him deistically, as out of all relation to history, as uninvolved in our problems and pains, as out of touch with our experiences. The Absolute God is, in their view, the Wholly-Other God. This God, they say, is a non-existent, certainly a non-existential God, the figment of the philosopher's imagination and they refuse to acknowledge him, preferring instead an immanent God who is joined with us in our struggles on the concrete plane of history. 
If there are some who refuse to predicate absoluteness of God, there are more who refuse to predicate it of religion, and by that token, of the Chrisian religion. Religion, they observe, is precisely what is not cut loose from process and the relativities of our existence. Religion, they point out, is a human affair, and like everything human, it is finite, imperfect, partial, changeable. How then, they ask, since Christianity is a religion, can anyone speak of it as absolute? It is temporal; it arose in time and is even now in process. Being relative it is essentially no different than any other religion. It may differ from other religions accidentally, in measure or degree, but at bottom it is as conditioned by time and circumstance as they are; it has no monopoly of truth or grace; it is not the only, the absolute, the final, the definitive religion. It may be the religion best suited to some men, and even the highest and best religion yet conceived, but it is not absolute.

What are we to say to this? Is there not force in these anti-absolutistic remarks? Is it, for example, not true that Christianity arose at a definite time and place; that its sacred books reflect the mind and spirit of the Jewish people, modified by the philosophical ideas elaborated by the Greeks and transmitted by the Romans; and that its institutions and practices express the genius of the Northern European peoples? Is Christianity not essentially Western in nature, and if not Western, then NearEastern or Semitic? And is it not on that account limited, partial, particular-ill-suited to other places and peoples, and even to other times?

Adolph Hitler thought so. Under the tutelage of Friedrich Nietzsche and Alfred Rozenberg he came to ascribe Europe's ills to the superimposition upon the Nordic race of a Semitic religion entirely out of accord with the decpest impulses of the Aryan spirit and he resolutely opposed Christianity as well as Jewry in the interest, he thought, of restoring Europe's spiritual health and saving it from religious schizophrenia. And was not Hitler right? Isn't it the duty of an awakened nationalism and a self-conscious racism to throw off, not indeed religion, but a non-indigenous religion which arrogantly exercises, as it has historically fostered, a culture-destroying spiritual imperialism? Should not different people, in different countries, in different historical contexts, find their own way to God and develop a religion suited to their own peculiar needs and circumstances? And will not political co-existence and international peace come into being and flourish only when on the spirituo-religious level extravagant and self-preferential claims are dropped and each is allowed in utter freedom to pursue his own spiritual destiny? Or, if in one world, one single religion is to weld all peoples together by the power of one spiritual force, must not this religion be an amalgam of the best in all religions, a synthesis of the religious insights of the 
entire race, and not the expression of a narrow and intolerant particularism?

The Laymen's Appraisal of thirty years ago, which was set down in a book called Retbinking Missions, thought so. In this book Jesus is regarded as no more than the world's most eminent religious genius. Jesus was a fellow-seeker with us after God, and we bear his name because in our quest of God we follow his lead. Christianity is not a religion about Christ but the religion of Christ. To ascribe an absolute finality to Christianity is to give expression to a spiritual arrogance entirely foreign to the spirit of the Master. Christianity is an ethical system which ought to be generously proffered to enquiring people, but it is not a way of salvation that must be urged upon people as an alternative to eternal death. The central aim and purpose of Christian missions is to serve men, not to change or rescue them. Too long, it is complained, have we regarded conversions as the zenith of missionary achievement, and a soul as a kind of spiritual scalp in our wigwam. We must remember that we are commissioned not to rob other people of their faith, but to "assist them to a truer interpretation of their own meaning." Christian missions are not proselyting agencies but only means of coming to terms with the ethnic religions. What the missionary asks of non-Christian peoples is not repentance and conversion, but greater depth or consistency in the practice of their native faith, for it is not only at Jerusalem nor only on Mt. Gerizim that God may be served, but on every way men walk in sincerity and uprightness, whether in the company of Gautama, Confucius, or Jesus. What can we say to this?

\section{SCRIPTURE}

The first thing we can say is that this is not the view entertained of Christianity in the Bible, which for us is the inspired and infallible rule of faith and practice, and which, on any theory of inspiration must be taken as an authoritative source of Christian teaching. The Bible clearly teaches not merely the superiority but also the exclusive validity of the Christian Way.

In John 14:6 Christ says of himself, "I am the way, the truth, and the life; no one cometh unto the Father except through me." In the light of this pronouncement the command of Christ in Matthew 28:18-20 stands forth in all its authority and urgency. Christ here proclaims himself Lord of the world, "All power is given unto me in heaven and earth"; the one Lord whose imperious claim on men's lives, though gracious, is comprehensive and unending, "even unto the end of the world."

This understanding of Christ animates the preaching of the Apostles, as can be seen, for example, from Peter's sermons in Acts. In Acts 
$2: 36,38$ we read, "Therefore let all the house of Israel know assuredly, that God hath made that same Jesus, whom ye have crucified, both Lord and Christ. ... [Wherefore] repent, and be baptized every one of you in the name of Jesus Christ for the remission of sins." And why repent and flee to Christ? The answer is given in Acts $4: 12$, ". . in none other is there salvation, for neither is there any other name under heaven, that is given among men, wherein we must be saved."

Because this is so, Paul, who determined not to know anything among men save Jesus Christ and him crucified, could say in Gal. 1:8, "Though we, or an angel from heaven preach any other Gospel unto you than that which we have preached unto you, let him be accursed." Paul, it is evident, regarded the gospel as final.

\section{THEOLOGY}

The reason the Christian Gospel is absolute and final is that its content, Jesus Christ, is absolute. As John tells us in John 1:1, "In the beginning was the Word, and the Word was with God, and the Word was God." Wherefore Jesus said in John 10:30, "I and my Father are one." Jesus Christ is no mere prophet; he is certainly no mere hero or genius; he is not a spark struck off the human block; he is not man reaching up to God. He is God identifying himself with man; he represents an incursion into this world from another world; he is God incarnate. In him God has come to men completely, fully, finally. There cannot be a revelation beyond this revelation. In Jesus Christ we have the absolute God standing in the most intimate relation to mankind without himself being thereby relativized. Here is Eternity standing in time yet not being temporalized. Here is the Other becoming the same, and yet not losing his otherness. Here is Finality in touch with process and giving it the only meaning it has.

What is true of Christ's person is true of his work. He came for one purpose only: To reconcile man to God. And since the reconciliation could be effected in one way only, it may be said that he came to die. To this end was he born. And when he died and arose again there was accomplished what need not and could not ever be done again. At the Cross and on Easter the power of sin was forever broken, the sting was taken out of death, and the grave was robbed of its victory. About the finality or once-for-allness of Christ's work the Scriptures do not leave us in doubt. Paul says in Romans 6:10: "For in that he died, he died unto sin once." Peter says in I Peter 3:18: "For Christ also hath once suffered for sins, the just for the unjust, that he might bring us to God." And the author of the Epistle to the Hebrews says in 9:26, 28, but now once in the end of the world hath he appeared to put away sin by the 
sacrifice of himself . . . So So Christ was once offered to bear the sins of many."

\section{RELIGION}

Because Christianity is concerned with the person and work of Christ it is final and absolute. Christianity is not a way of man to God (then it would be temporary and relative), but an account of God's dealing with men and of man's graciously initiated response to the divine activity. As such it is unique, distinguishing itself from all other religions, every one of which is the product of man's search after God while in flight from him or in rebellion against him. Christianity therefore must be radically distinguished from every ethnic faith. To all such faiths it stands in a relation of antithesis. With none of them can it come to terms or be combined. It cannot even be embraced with them in a comparative study such as is undertaken in the discipline called Comparative Religions. It cannot be embraced with non-Christian faiths in a comparative study because such a study invariably makes the comparison in terms of a standard other than and beyond the entities compared. Reference is invariably made to an abstract essence called religion, of which both Christianity and the other faiths are considered partial exemplifications. True religion is then regarded as a genus of which Christianity and the other religions are species. But this the Christian will not allow. Christianity is not a particular and therefore partial manifestation of an essence other than itself. It is itself the very essence of religion, and all other "religions" are so-called because of their negative relation to it, because of their defection and apostasy from the true worship of God restored in Christianity. Non-Christian "religions" are strictly speaking no religions at all, just as heathen "gods" are strictly speaking no gods at all. There is only one God, and there is only one religion, in the absolute sense. The God is Jehovah, who is a jealous God, and will not give his glory to another, nor his praise unto graven images (Isa. 42:8). The religion is Christianity, which is set over against all other so-called religions and is concerned to unmask them as hinderings of the truth in unrighteousness (Rom. 1:18-25), while calling their adherents on to the knowledge and fellowship of the one true God.

\section{ANTITHESIS}

Christianity in its uniqueness and absoluteness is set over against the ethnic faiths, but it is important to understand just wherein this antithesis resides. I suggest that what are set-over-against each other in the antithesis are not, primarily, two histories, nor two lives, nor even two theologies, but rather two principles, the principles of Sin and Grace.

1. The antithesis in all its radicality is not between two concrete 
historical entities, between historic Christianity and, for example, historic Buddhism. The history of these two magnitudes is governed to a large degree by common factors. Each is in great part the product of cultural, economic, political, and generally human causes and influences. In respect of these influences each may be compared to the other and subjected to a single analysis. Because they lie on the plane of history these two religions change their aspects with the times, and are at different times more or less true to themselves; the course described by each is not steady and linear, but full of ups and downs, of defections and reformations. On this plane Christianity as well as Buddhism stands under judgment, for it is here not only affected by the relativities of finite existence but also by human depravity.

2. The antithesis is also not, in the most radical sense, between two lives. A recognition of this fact will keep us from making a comparison of the behavior of a Buddhist and a Christian, and save us from the embarrassment which often attends such a comparison. It is a well-known fact that non-Christians are often more dedicated to their faith, more meticulous in their observance of their duties, more willing to sacrifice their private interests than is the Christian. There is always the noble pagan to shame the Christian. In this situation it must be remembered that it is no part of Christianity to say that our lives are better than those of the heathen. It is, as Christians, not our virtue we confess but our sins and weakness. We confess that we are unclean and undone, and this is not metely a pious mouthing but a declaration of literal truth. We acknowledge that we are not so much good as declared good in the juridical act of justification. And even when, through God's sanctifying Spirit, our lives are radiant with love, our failings are there to temper our pride, and to keep us from boasting or making odious comparisons. It is forever un-Christian to say "Lord, I thank thee that I am not like that publican." A recognition of this general truth will keep us, too, from intellectual confusion. It will help us unmask as pseudo-philosophy much discussion as to whether there is any knowledge or any virtue among the unbelievers. Of course there is such knowledge and virtue, and on the empirical level it often exceeds our own.

3. The antithesis is also in its deepest sense not between two theologies. Theologies, too, are human products, inevitably influenced by natural and human factors, which render them imperfect, changeable, criticizable. Theologies, including Christian theologies, lie in the judgment as well as human lives and historical institutions. Although against Barth we must maintain that there actually exist what he calls the "Blessed Possessors," yet it will never do to identify our theological constructions with the truth as it is in Jesus Christ, for then we cut off every possibility 
of reformation, and make ourselves guilty of a spurious absolutism. It should also be observed that on the level of theological reflection the antithesis is modified by the fact that Christian theology and theologiafalsa employ common intellectual instruments (methods and categories), and address themselves to much the same problems. A good illustration of this is found in the theological work in Europe in the 12th and 13th centuries, when, with a common appeal to Aristotle, Christian and Mohammedan alike were fashioning different theologies around a common set of problems, such as the authority of sacred Scripture, the relation between predestination and free will, the bearing of philosophy upon theology and vice-versa, and the relative value of Scripture and Tradition.

4. The antithesis that exists between Christianity and non-Christian religions is effected by the supernatural and absolute power of grace which is mediated to the world through Jesus Christ and his Spirit and through no one else. This grace which separates men and cuts the human race in two, was promised (and indeed imparted) in the early dawn of human history, soon after man yielded to the temptation of the devil and fell away from God. By that fall man came into the power of sin, from which there is no final release except through a counter-power, the power of grace, which God released in pre-Christian times in view of Christ's sacrificial death and in Christian times upon the basis of that sacrifice. Through grace there is called out of the mass of men those who by faith in Christ's name are saved from condemnation and ushered into life. And between those who are thus called out and those who remain under judgment there is a great gulf fixed, a gulf that none can cross unaided. And those on either side are very different, the one being in Christ, the other being outside of Christ; the one alive, the other dead; the one standing in the light, the other being in darkness; the one living from the principle of grace; the other from the principle of sin. Now, insofar as the term "Christianity" means the vehicle and expression of grace (and this is what it centrally does mean) it stands opposed to other religions as light to darkness, life to death, salvation to condemnation, for other religions, though they could not exist without the indelible sense of God impressed upon the soul, are nevertheless expressions of man's determination to serve not the one true God but only some creature that God has made; and from such creatures, who themselves are alienated from God, no way can be found that leads to God and blessedness. There is only one way to God, the way laid by God himself-his only begotten Son, the Savior of the world-the way upon which Christians walk, the way which, if one walk upon it, one is a Christian, an adherent of the Christian religion, a member of the Christian Church. The Christian Way is therefore unique, absolute, incomparable, for it is Christ himself, very 
God of very God. This, then, is what we mean when we say that Christianity is absolute, and opposed antithetically to all other religions.

What does this mean for our understanding of religion in general, and for non-Christian religions in particular?

It means, negatively, that, standing within the perspective of Christianity, we cannot take the phenomena of the non-Christian religions as the key to the meaning of religion or to the meaning of the religious life, but rather that this key must be found exclusively in the revelation set down in the Christian Scriptures, the Bible, by whose light alone man and his works can be truly understood. It means, too, that we cannot regard non-Christian religions evolutionistically as approaches or stepping stones to Christianity. They are rather deviations from Christianity, lapses from the true religion, movements away from truth and beatitude. They are at bottom false, being animated centrally by the sinful rejection of God's right to define himself and to prescribe how he should be worshipped. It also means, therefore, that we do not represent Christianity as merely different than non-Christian religions, but rather as radically otber than these religions, it being true, the others false-remembering always that this is a judgment of faith, and not empirically verifiable, and remembering too that since it is a judgment of faith it will give offense to those who stand outside the faith. It means finally that we are obliged to press the non-Christian worshipper, not merely for improvement, but for repentance and for a decision to break with his false gods.

If the true nature of all religions is disclosed within the perspective of the Christian religion, this enables us not only to pass a negative judgment upon non-Christian religions, but it also enables us to explain the characteristic complexity of these religions, to explain that curious play of lights and shadows which is such an undeniable feature of their existence. For though all religions, other than the religion of Christ, are false at the center, displeasing to God, and unable to save, there is yet in them an unwitting acknowledgement of God, there is power in some of them to raise the level of men's moral behavior and they keep alive in men's consciousness the reality of the Unseen. They are so far forth a protest against atheism, immorality, and radical secularism. Now, far from denying that these features exist in ethnic religions, Christianity calls our attention to them and provides us with the principles in terms of which to account for their existence. There are at least four such principles disclosed in Scripture. They are:

1. The sensus divinitatis or the cognitio dei innota- an inner, unquenchable awareness of God, owing to man's being made in God's image, and retaining it in the broader sense in spite of all the ravages of sin.

2. General Revelation-a display in nature and history of God's 
might and divinity, a display which does not entirely escape the notice of sinful men, for the reason that God's display or revelation of himself is always effectual after its kind. The power of sin which reigns in the heart of the unregenerate is not strong enough to shut God out. His witness still comes through the barrier of their resistance, and, though nonChristians try to suppress, and fundamentally misinterpret what God is saying, they do apprehend something of him, and what they apprehend is recognized by the Christian to be of value.

3. Common Grace-a disposition and power of God which, without working regeneration and salvation, arrests the power of sin to blind and destroy, and gives good gifts to the rebellious.

4. Special Revelation-which appears in non-Christian religions in a two-fold way: First, as a borrowing from the Jewish and Christian faiths. A good example of this is Mohammedanism, many of whose brighter spots are owing to a kind of orientation to Old and New Testaments. Other examples are found in certain reform movements in Hinduism.Special Revelation appears in non-Christian religions, secondly, as a memory or tradition, a memory dim and distorted of the original revelation to Adam in Paradise, and to himself and his descendants before the formation of God's special people Istael.

When once we have gotten these principles and facts in view, when once we give due weight to the innate sense of God, general revelation, common grace, and the indelible memory of God's dealings with men before the separation of his chosen people, then we will understand that it is contrary to both fact and Scripture to regard the ethnic faiths as (simplistically) nothing but the outworkings of sin, notbing but the work of Satan. There is grace in them too-not saving grace, and there is no salvation in them-but grace nevertheless, the presence of which is, of course, not an occasion to congratulate the sinner, but to magnify the Lord.

It is this complexity which makes true on the one hand the declaration of Paul in Romans 8:7 that "the carnal mind is enmity against God," and on the other that the sinner in some sense is a seeker after God, being restless until he rests in him, as we learn from Acts 17:27, "that they should seek God, if haply they might feel after him and find him."

We see, accordingly, that Christianity is both the denial of the ethnic faiths and the fulfillment of them. It is a rejection of them, and an answer to their questions. It is this complex relationship which gives significance to the missionary enterprise.

Missionary work is necessary because the natural man is lost, without Christ, no man being able to be saved by even the most diligent observance of the prescriptions of the ethnic faiths.

And missionary work is possible because God has been beforehand with the people to whom the missionary addresses the Gospel, and has provided a living point of contact for him. 